\title{
Erratum to: The Impact of Independence and Brand Personality on Brand Evaluations Among Biculturals
}

\author{
Umut Kubat
}

(C) Springer International Publishing Switzerland 2017

M.H. Bilgin et al. (eds.), Financial Environment and Business Development, Eurasian Studies in Business and Economics 4,

DOI 10.1007/978-3-319-39919-5_39

In the chapter titled "The Impact of Independence and Brand Personality on Brand Evaluations Among Biculturals" there was a typo in the author name Umut Kuba.

The name should read as "Umut Kubat".

The updated original online version for this chapter can be found at DOI 10.1007/978-3-319-39919-5_39

\footnotetext{
U. Kubat $(\square)$

Business School, Yildirim Beyazit University, Ankara, Turkey

e-mail: ukubat@ybu.edu.tr
} 